\title{
Mitochondrial DNA differentiation among geographical populations of Pronolagus rupestris, Smith's red rock rabbit (Mammalia: Lagomorpha)
}

\author{
CONRAD A. MATTHEE \& TERENCE J. ROBINSON* \\ Department of Zoology and Entomology, University of Pretoria, Pretoria 0002, South Africa
}

\begin{abstract}
Geographical genetic population structure was determined for an endemic African leporid, Smith's red rock rabbit, Pronolagus rupestris. Restriction fragment length polymorphism analysis of mitochondrial DNA from 55 specimens revealed 32 distinct maternal lineages for the 21 populations sampled. The data show two major genetic assemblages separated by a mean sequence divergence of 7.94 per cent $( \pm 1.40$ per cent $)$ and provide little support for the continued recognition of most of the described subspecies. The south-eastern assemblage is confined to the mountain ranges comprising the Great Escarpment of South Africa, while the north-western assemblage is not so tightly constrained. With the possible exception of elevation, no readily apparent ecological or topographical barrier could be identified which delimits the two mitochondrial clades. The sequence divergence separating the south-eastern and north-western $P$. rupestris clades is high, and approximates the interspecific sequence divergences detected between $P$. rupestris and other Pronolagus species. The two P. rupestris clades are parapatric for part of their distribution, and the absence of shared mtDNA lineages is consistent with the hypothesis that the two populations are reproductively isolated from each other. We provisionally interpret this to reflect the presence of two hitherto undetected biological species in what has conventionally been recognized as a single taxon, $P$. rupestris.
\end{abstract}

Keywords: mitochondrial DNA, phylogeography, population structure, Pronolagus rupestris, rabbit.

\section{Introduction}

The geographical patterns of genetic variation detected within species are the product of both historical and contemporary gene flow (Slatkin, 1987) and are mediated by factors that tend to produce population subdivision including limited dispersal capabilities, strong territoriality, patchiness of the environment and social structuring. Many of these life history traits characterize the African rock or 'koppie' dwelling mammalian fauna such as the rock hyrax (Procavia capensis), elephant shrews (Family Macroscilididae), the klipspringer (a specialist antelope, Oreotragus oreotragus) and red rock rabbits of the genus Pronolagus. In this study we focus specifically on one of the saxicolous species,

\footnotetext{
${ }^{*}$ Correspondence.
}

Smith's red rock rabbit, $P$. rupestris, an African endemic which occurs south of the Sahara (Fig. 1). The species's distribution is characterized by a southern population confined largely within the borders of South Africa, and an east African isolate which extends from northern Malawi, through eastern Zambia and central Tanzania to southwestern Kenya (Smithers, 1983). Their microgeographical occurrence is highly dependent on the availability of substantial rocky shelter (krantzes, rocky hillsides, boulder-strewn koppies and rocky ravines) which often occurs in the form of disjunct 'terrestrial islands'. The intervening unsuitable habitat may produce isolated populations and result in a relatively high degree of genetic differentiation between local demes.

Our study of the patterns of geographical variation in mtDNA of Smith's red rock rabbit was 
Fig. 1 Pan African distribution of Pronolagus rupestris (inset) and the South African collection localities of specimens used in this investigation. A: Kuruman; B: Bloemfontein; C: Campbell; D: Springbok; E: Donkerpoort; F: Ladismith; G: Grahamstown; H: Golden Gate National Park; I: Howick; J: Matatiele; K: Dealesville; L: Prieska; M: Nieuwoudtville; $\mathrm{N}$ : Verkeerdevlei; O: Victoria-West; P: Sandgat; Q: Rolfontein; R: Volksrust; S: Waterval Boven; X: Lydenburg; Y: Blydepoort Nature Reserve.

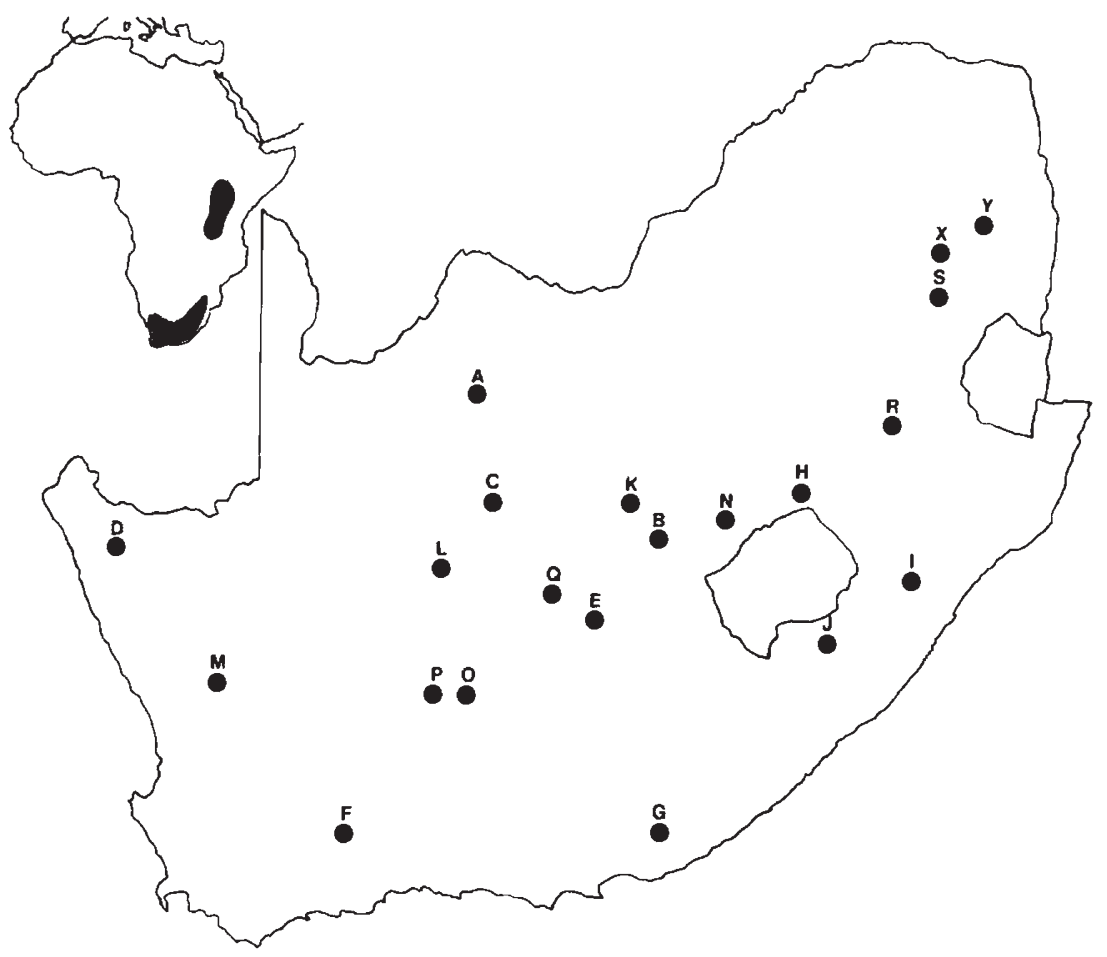

prompted by two concerns. First, given the apparent morphological differentiation (Roberts, 1951; Ellerman et al., 1953; Petter, 1972) among the seven currently recognized southern African subspecies (Meester et al., 1986), and the sometimes marked geographical discontinuities distinguishing many populations, molecular measures of divergence might be expected to reveal regional genetic differences between populations. Secondly, as deep divisions in an infraspecific phylogeny represent a major source of gene pool diversity within a species (Avise, 1992), our investigation has clear conservation implications. Whereas $P$. rupestris, as currently understood, is well represented in the existing network of protected areas in southern Africa, the detection of deep genetic partitioning could indicate the presence of 'Evolutionary significant units' (ESUs; Ryder, 1986) which fall outside of these areas. Although the purpose of conserving ESUs is to protect the evolutionary potential of major clades within a species, an initial step in this process is the analysis of historical population structure.

The work presented here is part of a broader study relating to geographical mtDNA variability within a number of saxicolous species (Prinsloo \& Robinson, 1992). Our ultimate aim is to attempt to understand the microevolutionary processes involved in shaping the phylogeographical structure of the African mammalian 'koppie' fauna. Avise et al. (1987) proposed that concordant mtDNA profiles detected among the intraspecific phylogenies of ecologically similar, but phylogenetically unrelated, species may reveal historical features that figure prominently in regional biogeography. Additionally, should a common trend emerge from our investigations of selected African 'koppie' dwelling species it would be of profound conservation significance. This is especially so if the molecular data show particular geographical regions which are characterized by high intraspecifc biogenetic diversity, and therefore represent foci worthy of consideration for regional conservation actions (Avise, 1992).

Our aims in this investigation were threefold: (i) to determine whether the mtDNA variation in $P$. rupestris is geographically structured; (ii) whether evolutionary lineages revealed by mtDNA analysis are concordant with conventional subspecies boundaries; and (iii) whether there is any agreement in phylogeographical pattern between $P$. rupestris and published data on the rock hyrax, Procavia capensis (Order Hyracoidea), a species with similar habitat requirements and whose distribution in South Africa overlaps significantly with $P$. rupestris (Prinsloo \& Robinson, 1992). 


\section{Materials and methods}

Pronolagus rupestris specimens $(N=55)$, which included representatives of six of the seven southern African subspecies, were collected from 21 localities within South Africa (Fig. 1). Heart, liver and kidney samples were frozen in liquid nitrogen and transferred to an ultra cold freezer $\left(-70^{\circ} \mathrm{C}\right)$ until processed. Intact mtDNAs were isolated using conventional procedures (Lansman et al., 1981). Mitochondrial DNA (10-50 ng) was digested using 14 Type II restriction enzymes following the manufacturer's recommendation (Promega and Boehringer Mannheim). The resulting fragments were end-labelled using $0.25 \mu \mathrm{Ci} \alpha-{ }^{32} \mathrm{P}$-dCTP/dATP in combination with the other three unlabelled nucleotides and separated by horizontal gel electrophoresis using 1-2 per cent agarose slab gels. The end-labelled fragments were dried onto Whatman 3 MM chromatography paper and visualized by standard autoradiography. In instances where we were unable to resolve some of the smaller fragments $(<500 \mathrm{bp})$ because of lane background, Southern blotting (Southern, 1975) of mitochondrial DNA was used (see Prinsloo \& Robinson, 1992). In these instances hybridization membranes were screened using purified oligolabelled Pronolagus mtDNA as probe (Feinberg \& Vogelstein, 1983). This approach was particularly useful with digestions involving StyI where a large number of fragments (10-12) were generated which ranged between 5.75 and $0.55 \mathrm{~kb}$.

Estimates of nucleotide sequence diversity $(d$; within populations) and divergence (between haplotypes) were based on the fraction of shared restriction fragments, and calculated using REsTsite v.1.1. (Nei \& Miller, 1990). Two hundred bootstrap replicates were performed to estimate standard errors with a correction applied to $d$-values to avoid underestimation caused by large nucleotide substitution values (Jukes \& Cantor, 1969). The resulting distance matrix was analysed by Neighbour-Joining (Satou \& Nei, 1987) and a mtDNA phylogeny of the haplotypes obtained.

Genotypic diversity $(h)$ within clades was calculated using $n\left(1-\Sigma f_{i}^{2}\right) /(n-1)$ (Nei \& Tajima, 1981) where $f_{i}$ is the frequency of the $i$ th mtDNA genotype in a sample of size $n$ (Avise et al., 1989). An estimate of population subdivision $\left(N_{\mathrm{st}}\right)$ was made by calculating the fraction of nucleotide variation within and between populations (Lynch \& Crease, 1990); all populations where fewer than three specimens were sampled were excluded. The $D$ statistic was used as an estimate of significance with $D>3.84$ rejecting the hypothesis of no population subdivision at the 5 per cent significance level (Lynch \& Crease, 1990).

Phylogeographical parsimony networks were constructed between haplotypes by calculating the number of site changes between different restriction fragment patterns for each enzyme (Avise et al., 1979a). The different mtDNA haplotypes were subsequently compared in a pairwise fashion and the amount of changes summed over all enzymes used. Finally, the different lineages were connected in a phylogenetic network comprising the minimum number of mutational steps between linked populations and the network subsequently overlaid on a map of the region.

\section{Results}

Our analysis of the 55 P. rupestris specimens revealed 60 different restriction fragment profiles (Fig. 2). Estimates of mtDNA variation were based on a total of 2873 fragments resulting in a mean of 52.24 fragments per specimen. The size of the mitochondrial genome of this species was estimated at $18.00 \mathrm{~kb}$ $( \pm 164 \mathrm{bp}$ ), in the upper size range reported for mammals (Brown, 1983) but in good agreement with other leporids (Biju-Duval et al., 1991); approximately 1.74 per cent of the mtDNA genome was analysed. In some instances heteroplasmy was observed. A similar situation exists in the domestic rabbit, Oryctolagus cuniculus, Lepus and Sylvilagus (Biju-Duval et al., 1991) and, with the addition of Pronolagus, is a phenomenon probably shared by all leporids. Where heteroplasmy was detected with specific enzymes this was readily distinguishable from site differences, and was consequently ignored in the calculation of the Pronolagus mitochondrial genome size.

Thirty-two haplotypes (Table 1) were identified from the 21 geographically discrete $P$. rupestris populations surveyed in this study. Pairwise estimates of nucleotide divergence between haplotypes are given in Table 2 and the maximum number of haplotypes detected in any single population was four (Golden Gate National Park, locality H; Lydenburg, locality $\mathrm{X})$.

The relationship among the 32 haplotypes is summarized in the Neighbour-Joining tree presented in Fig. 3a. Two major lineages of Smith's red rock rabbit are evident in South Africa: a larger and geographically more extensive lineage which occurs in the south-eastern regions of the country (haplotypes 10-32), whereas a second lineage comprising haplotypes 1-9 is found in the north-west. Although 

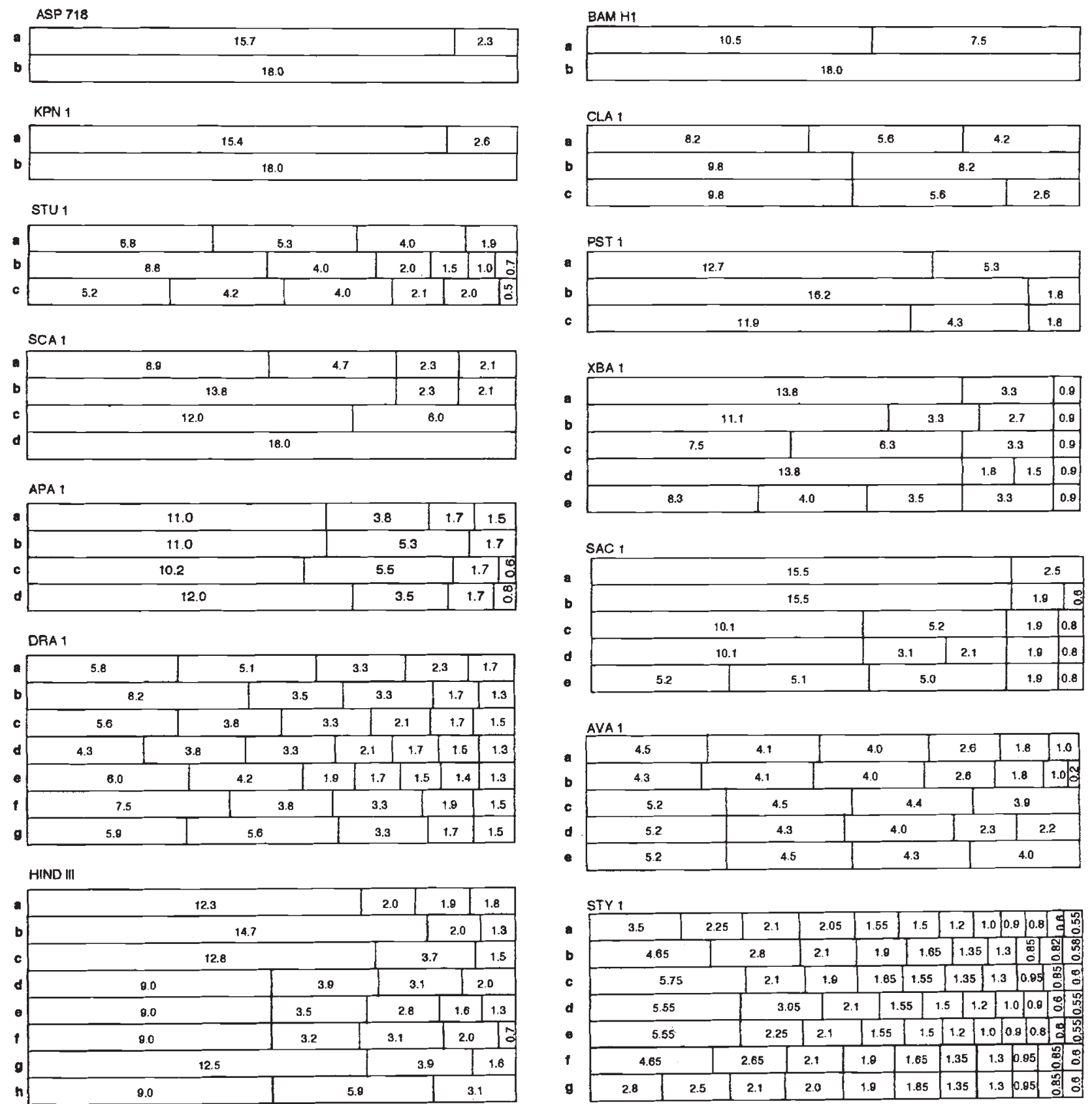

\begin{tabular}{|c|c|c|c|c|c|c|c|c|c|c|}
\hline & 3.5 & 2.25 & 2.1 & 2.05 & 1.55 & 1.5 & 1.2 & 1.010. & \begin{tabular}{l|l|}
.9 & 0.8
\end{tabular} & 承周 \\
\hline b & \multicolumn{2}{|c|}{4.65} & 2.8 & 2.1 & 1.8 & 1.65 & 1.3 & \begin{tabular}{l|l}
35 & 1.3
\end{tabular} & 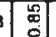 & (स) \\
\hline$c$ & \multicolumn{2}{|c|}{5.75} & 2.1 & 1.8 & 1.85 & 1.55 & 1.35 & \begin{tabular}{l|l}
5 & 1.3
\end{tabular} & 0.85 & T4 \\
\hline d & \multicolumn{2}{|c|}{5.55} & 3.0 & & & .55 & .5 & \begin{tabular}{l|l}
1.2 & 1.0
\end{tabular} & \begin{tabular}{l|l|l|}
0.8 & 0.8
\end{tabular} & $:$ \\
\hline$\bullet$ & \multicolumn{2}{|c|}{5.55} & 2.25 & 2.9 & 1.55 & 1.5 & \begin{tabular}{|l|}
1.2 \\
\end{tabular} & \begin{tabular}{|l|l}
1.0 & \\
\end{tabular} & \begin{tabular}{l|l|l|}
0.8 &
\end{tabular} & $8:$ \\
\hline $\boldsymbol{T}$ & \multicolumn{2}{|c|}{4.65} & 2.65 & 2.1 & 1.8 & 1.65 & 1.35 & 1.30 & 0.95 & \\
\hline & 2.8 & 2.5 & 2.1 & 2.0 & 1.8 & 1.85 & 1.35 & 1.30 & 0.95 & \\
\hline
\end{tabular}

Fig. 2 Graphical representation of the mtDNA restriction fragments generated by a suite of 14 type II endonucleases for Pronolagus rupestris. Fragment sizes have been scaled so that their sum equals overall mean mitochondrial genome size.

there is no evidence in the south-eastern cluster to support any of the current subspecies designations, it is noteworthy that within the north-western clade two pronounced subclades occur: one comprising specimens from geographically quite distant populations which contains specimens predominantly from the subspecies $P$. r. melanurus and $P$. r. rupestris, and the second subclade consisting of specimens referable on traditional characters to $P$. $r$ curryi.

(C) The Genetical Society of Great Britain, Heredity, 76, 514-523.
The unordered parsimony network, based on the least number of mutational steps between haplotypes, was superimposed on the geographical sources of collections (Fig. 3b) and, as with the NeighbourJoining tree, clearly shows the same two major mtDNA clades. The north-western clade is situated predominantly in the northern parts of the Cape Province, but includes parts of the Orange Free State, whereas the more extensive south-eastern 
Table 1 Mitochondrial haplotypes observed in 55 specimens of Pronolagus rupestris

Composite restriction profile

Haplotype No. of designation specimens AspI BamHI ClaI KpnI PstI XbaI SacI StuI ApaI ScaI DraI AvaI HindIII StyI

\begin{tabular}{|c|c|c|c|c|c|c|c|c|c|c|c|c|c|c|c|}
\hline 1 & 1 & $\mathrm{a}$ & $\mathrm{a}$ & $\mathrm{a}$ & $\mathrm{a}$ & $\mathrm{a}$ & $\mathrm{a}$ & $\mathrm{a}$ & $\mathrm{a}$ & $\mathrm{a}$ & $\mathrm{a}$ & $\mathrm{a}$ & $\mathrm{a}$ & $\mathrm{a}$ & $\mathrm{d}$ \\
\hline 2 & 2 & $\mathrm{a}$ & $\mathrm{a}$ & b & $\mathrm{a}$ & $\mathrm{a}$ & $\mathrm{a}$ & $\mathrm{a}$ & $\mathrm{a}$ & $\mathrm{a}$ & $\mathrm{a}$ & $\mathrm{a}$ & $\mathrm{a}$ & $\mathrm{a}$ & d \\
\hline 3 & 1 & $\mathrm{a}$ & $\mathrm{a}$ & b & $\mathrm{a}$ & $\mathrm{a}$ & $\mathrm{a}$ & $\mathrm{a}$ & $\mathrm{a}$ & $\mathrm{a}$ & $\mathrm{a}$ & $\mathrm{a}$ & $\mathrm{a}$ & $\mathrm{a}$ & $\mathrm{e}$ \\
\hline 4 & 1 & $\mathrm{a}$ & $\mathrm{a}$ & b & $\mathrm{a}$ & $\mathrm{a}$ & b & $\mathrm{a}$ & $\mathrm{a}$ & b & b & $\mathrm{a}$ & $\mathrm{a}$ & $\mathrm{a}$ & $\mathrm{e}$ \\
\hline 5 & 1 & $\mathrm{a}$ & $\mathrm{a}$ & $\mathrm{c}$ & $\mathrm{a}$ & $\mathrm{a}$ & $\mathrm{b}$ & $\mathrm{a}$ & $\mathrm{a}$ & $\mathrm{b}$ & $b$ & $\mathrm{a}$ & $\mathrm{a}$ & $\mathrm{a}$ & $\mathrm{e}$ \\
\hline 6 & 1 & $\mathrm{a}$ & $\mathrm{a}$ & b & $\mathrm{a}$ & $\mathrm{a}$ & $\mathrm{b}$ & $\mathrm{a}$ & $\mathrm{a}$ & b & $\mathrm{a}$ & $\mathrm{a}$ & $\mathrm{a}$ & $\mathrm{a}$ & $\mathrm{e}$ \\
\hline 7 & 1 & $\mathrm{a}$ & $\mathrm{a}$ & b & $\mathrm{a}$ & $\mathbf{a}$ & $\mathrm{a}$ & $\mathrm{a}$ & $\mathrm{a}$ & $b$ & $\mathrm{a}$ & $\mathrm{a}$ & $a$ & $\mathrm{a}$ & $\mathrm{e}$ \\
\hline 8 & 1 & b & $\mathrm{a}$ & b & b & $\mathrm{a}$ & $\mathrm{c}$ & b & $\mathrm{a}$ & $\mathrm{c}$ & $\mathrm{a}$ & b & $\mathrm{a}$ & b & $\mathrm{a}$ \\
\hline 9 & 1 & b & $\mathrm{a}$ & $b$ & b & $\mathrm{a}$ & $c$ & b & $\mathrm{a}$ & $c$ & $\mathrm{a}$ & b & $\mathrm{b}$ & b & $\mathrm{a}$ \\
\hline 10 & 1 & b & b & b & b & b & $\mathrm{a}$ & $\mathrm{c}$ & $b$ & $\mathrm{~d}$ & $c$ & $\mathbf{g}$ & $c$ & $c$ & $\mathrm{~b}$ \\
\hline 11 & 2 & $\mathrm{~b}$ & b & b & $b$ & $c$ & $\mathrm{~d}$ & $c$ & $\mathrm{c}$ & $\mathrm{d}$ & $\mathrm{c}$ & $c$ & $c$ & $c$ & c \\
\hline 12 & 1 & b & b & b & b & b & $\mathrm{a}$ & $\mathrm{c}$ & b & $\mathrm{d}$ & $c$ & $\mathrm{~d}$ & $\mathrm{c}$ & $c$ & b \\
\hline 13 & 1 & b & b & b & $b$ & $b$ & $\mathrm{a}$ & $c$ & b & $\mathrm{d}$ & $c$ & $\mathrm{e}$ & $c$ & $c$ & $\mathrm{D}$ \\
\hline 14 & 4 & b & b & $\mathrm{b}$ & b & $c$ & $\mathrm{a}$ & $\mathrm{c}$ & b & $\mathrm{d}$ & c & $\mathrm{d}$ & $\mathrm{d}$ & c & $\mathrm{c}$ \\
\hline 15 & 1 & $b$ & b & b & $b$ & $c$ & $\mathrm{c}$ & $c$ & b & $\mathrm{d}$ & $\mathrm{d}$ & $\mathrm{d}$ & $c$ & $\mathrm{~d}$ & $\mathrm{f}$ \\
\hline 16 & 1 & $\mathrm{~b}$ & b & b & $b$ & $b$ & $\mathrm{a}$ & $c$ & $\mathrm{c}$ & $\mathrm{d}$ & $\mathrm{d}$ & $\mathrm{f}$ & $\mathrm{c}$ & $\mathrm{e}$ & b \\
\hline 17 & 1 & $b$ & b & b & $\mathrm{b}$ & $c$ & $\mathrm{a}$ & $\mathrm{c}$ & b & $\mathrm{d}$ & $\mathrm{c}$ & $\mathrm{d}$ & $\mathrm{c}$ & $\mathrm{f}$ & $\mathbf{f}$ \\
\hline 18 & 1 & b & b & b & $b$ & $b$ & $c$ & $\mathrm{~d}$ & $\mathrm{c}$ & $\mathrm{d}$ & $c$ & f & $c$ & $\mathbf{g}$ & $\mathrm{g}$ \\
\hline 19 & 1 & b & b & b & $b$ & b & $\mathrm{a}$ & $c$ & $\mathrm{c}$ & $\mathrm{d}$ & $c$ & f & $\mathrm{c}$ & $c$ & b \\
\hline 20 & 1 & b & b & b & $\mathrm{b}$ & $\mathrm{b}$ & $\mathrm{a}$ & $c$ & $\mathrm{c}$ & $\mathrm{d}$ & $c$ & f & $\mathrm{c}$ & $c$ & $c$ \\
\hline 21 & 1 & b & b & b & $b$ & b & $\mathrm{c}$ & $c$ & b & $\mathrm{d}$ & $\mathrm{d}$ & f & $c$ & $\mathrm{~h}$ & b \\
\hline 22 & 2 & b & b & b & b & b & $a$ & $c$ & b & $\mathrm{d}$ & $\mathrm{d}$ & f & $\mathrm{c}$ & $\mathrm{e}$ & b \\
\hline 23 & 1 & b & b & b & $\mathrm{b}$ & b & $\mathrm{a}$ & $c$ & b & $\mathrm{d}$ & $c$ & $\mathrm{f}$ & $c$ & $\mathrm{e}$ & b \\
\hline 24 & 1 & b & b & b & b & $b$ & $c$ & $c$ & $\mathrm{c}$ & $\mathrm{d}$ & $\mathrm{c}$ & $\mathrm{d}$ & $c$ & $c$ & b \\
\hline 25 & 3 & $b$ & b & b & $b$ & $c$ & $\mathrm{a}$ & $c$ & $c$ & $\mathrm{c}$ & $\mathrm{d}$ & $\mathrm{d}$ & $c$ & $\mathrm{f}$ & $\mathrm{c}$ \\
\hline 26 & 2 & b & b & $b$ & $\mathrm{~b}$ & $c$ & $\mathrm{a}$ & $\mathrm{e}$ & $\mathrm{c}$ & $c$ & $\mathrm{~d}$ & $\mathrm{~d}$ & $c$ & $\mathrm{f}$ & $c$ \\
\hline 27 & 2 & $\mathrm{~b}$ & b & $b$ & b & $c$ & $\mathrm{e}$ & c & $\mathrm{c}$ & $c$ & d & f & $\mathrm{e}$ & f & b \\
\hline 28 & 2 & b & b & b & b & $c$ & $\mathrm{a}$ & $c$ & $c$ & $\mathrm{~d}$ & $\mathrm{c}$ & $\mathrm{d}$ & $\mathrm{c}$ & f & $c$ \\
\hline 29 & 3 & b & b & b & b & $c$ & $\mathrm{c}$ & $\mathrm{c}$ & $c$ & $\mathrm{c}$ & $\mathrm{d}$ & $\mathbf{f}$ & $\mathrm{e}$ & f & b \\
\hline 30 & 9 & b & b & b & b & $c$ & $c$ & $c$ & c & $c$ & $\mathrm{~d}$ & $\mathrm{~d}$ & $\mathrm{e}$ & $\mathrm{f}$ & b \\
\hline 31 & 3 & b & b & b & b & $c$ & $\mathrm{a}$ & $\mathrm{c}$ & $c$ & $c$ & $\mathrm{~d}$ & $\mathrm{~d}$ & $\mathrm{e}$ & f & b \\
\hline 32 & 1 & b & $\mathrm{b}$ & b & b & $c$ & $\mathrm{a}$ & $c$ & $c$ & $c$ & $\mathrm{~d}$ & $\mathrm{f}$ & $\mathrm{e}$ & f & b \\
\hline
\end{tabular}

clade loosely follows the mountain ranges comprising the Great Escarpment of South Africa (Bristow \& Ward, 1988). This analysis reveals that at least 45 mutational steps separate the maternal lineages present in the north-western clade (haplotypes 1-9) from those in south-eastern clade (haplotypes 10-32). There are no shared lineages between the two metapopulations. Although most of the haplotypes in the latter are separated by relatively high numbers of restriction site changes, this is in sharp contrast to the patterns detected in north-western reaches of the country. In this clade single site changes invariably separate matrilines (even geographically distant ones), the only exception being haplotypes 8 and 9 of the Kuruman population (locality A, Fig. 1) which are distinguished by 11 site changes from their nearest relatives. Additionally, the fragment profiles of nine of 14 restriction enzymes were clade-specific (AvaI; Bam HI; DraI; HindIII; PstI; SacI; ScaI; StuI; StyI; Fig. 2) whereas the endonucleases $C l a \mathrm{I}$ and $X b a \mathrm{I}$, which were polymorphic, failed to separate the two clades. Specimens from Kuruman in the north-western clades shared restriction fragment profiles (AspI, KpnI, $A p a \mathrm{I})$ with individuals from the larger south-eastern clade.

The two major geographical lineages were separated by a mean sequence divergence of 7.94 per cent $( \pm 1.40$ per cent) with the two most divergent haplotypes (numbers 5 vs. 27), and least divergent (numbers 8 vs. 25) yielding estimates of 12.45 per cent $( \pm 1.62$ per cent) and 5.95 per cent $( \pm 1.09$ per 


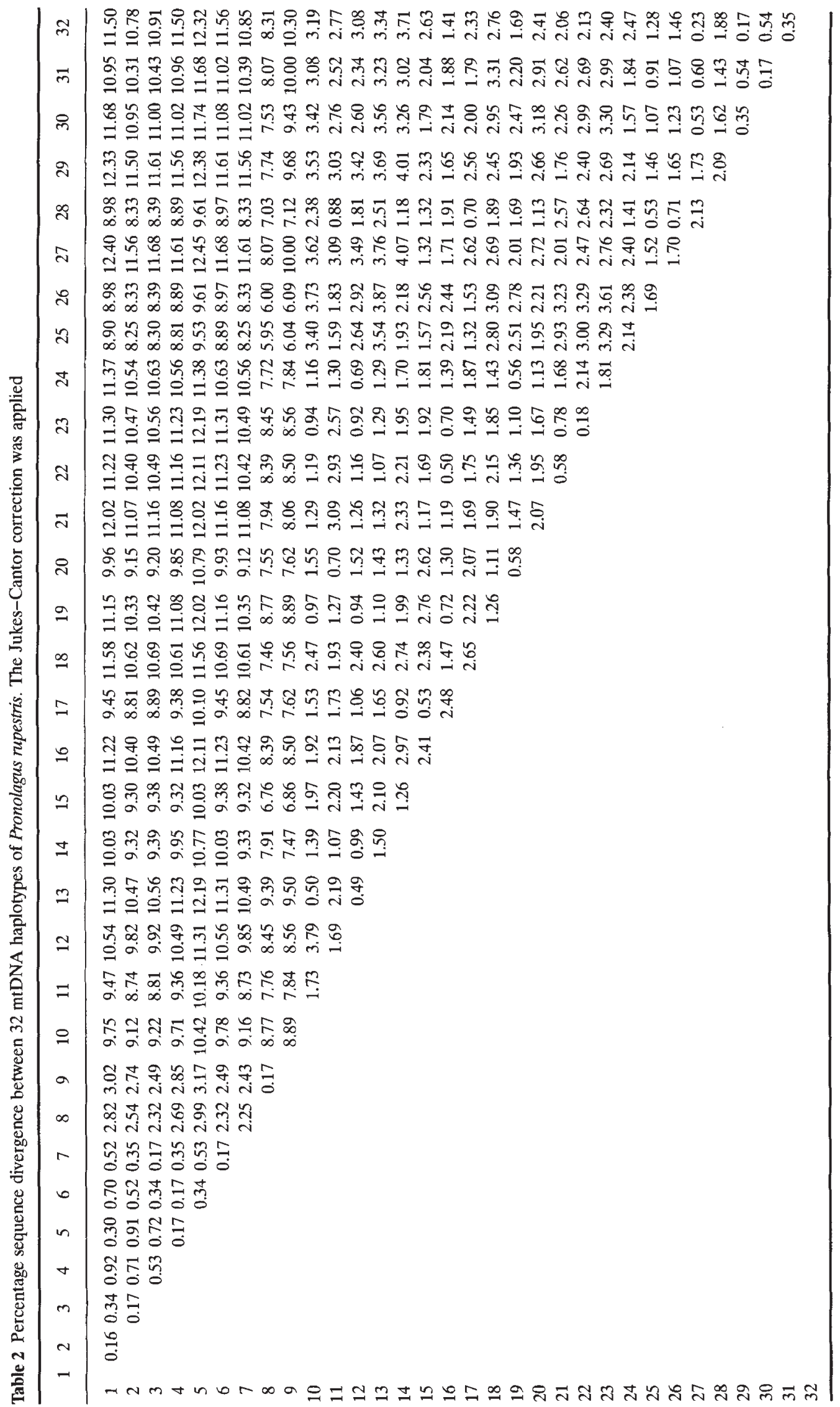


(a)

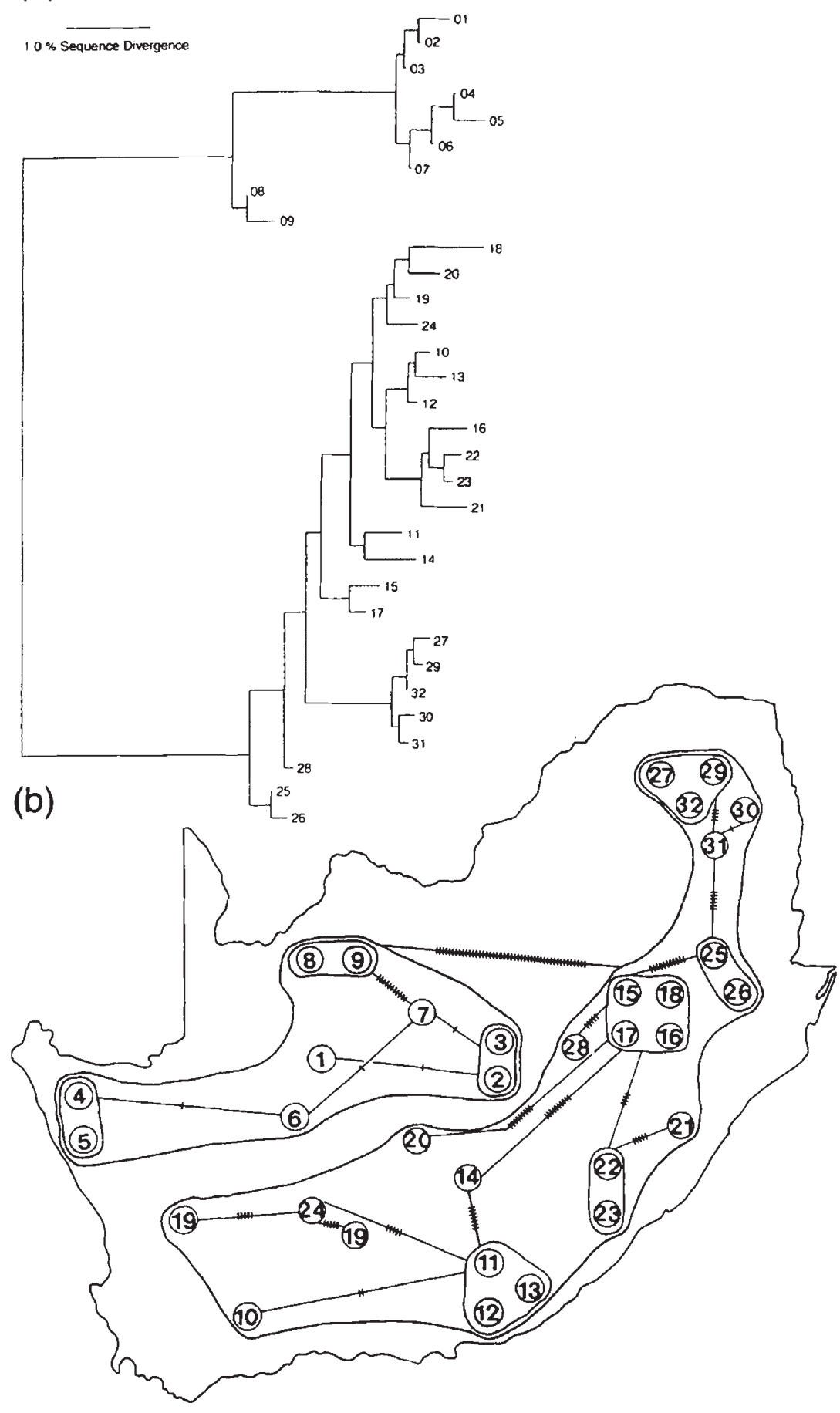

Fig. 3 (a) Neighbour-Joining tree based on mtDNA sequence divergence between 32 Pronolagus rupestris haplotypes. Haplotypes 1-9 are representative of the north-western clade and 10-32 the south-eastern clade. (b) Phylogeographical network based on the minimum number of mutational steps between $P$. rupestris maternal lineages. Bars along connecting branches indicate the least number of mutational steps between haplotypes.

cent), respectively. Sequence diversities of 1.09 per cent $( \pm 0.22$ per cent) within the north-western clade and 1.69 per cent $( \pm 0.34$ per cent) within the south-eastern clade were found. Genotypic diversity was estimated at 0.958 for the north-western clade and 0.866 for the south-eastern clade. The north- western clade was excluded from the $N_{\text {st }}$ calculations because of a lack of sufficient numbers of individuals in the seven different populations. The eight populations included from the south-eastern clade showed a statistically significant differentiation with an $N_{\text {st }}$ value of $0.246(D$ statistic $=6.3507 ; \mathrm{SE}= \pm 0.098)$. 


\section{Discussion}

The most striking result to emerge from this study is the presence of two major genetic and geographically distinct maternal lineages within $P$. rupestris: one located in the south-eastern portion of South Africa, and the other in the north-west. The population structure is, with few exceptions, not concordant with the current subspecific taxonomy of $P$. rupestris. Although geographically not well delineated (Meester et al., 1986) the rupestris, curryi and melanurus subspecies all fall within the north-western clade with barretti, australis and saundersiae clustering within the south-eastern clade. Although stochastic mtDNA lineage survivorship (Avise, 1989) could probably be invoked to account for the lack of concordance with previously described subspecies boundaries, it seems that with the exception of the genetically distinct Kuruman population in the north-western clade (specimens of which, using existing keys, are referable to $P$. $r$. curryi), the remaining subspecies as currently delineated probably do not represent valid taxonomic entities.

Equally striking is the fact that the marked mtDNA discontinuity detected in Smith's red rock rabbit does not coincide with that of the rock hyrax (Procavia capensis; Prinsloo \& Robinson, 1992), a species with similar habitat requirements and codistribution, therefore excluding the effects of a common vicariant event on their phylogeography. The rock hyrax discontinuity is thought to reflect dispersal along two separate routes which show fidelity to mountain ranges comprising the Great Escarpment and those of the Soutpansberg-Magaliesberg axis (see Fig. 3 in Prinsloo \& Robinson, 1992). Although the south-eastern $P$. rupestris clade seems similarly bound to the mountain ranges and abutting regions of the Great Escarpment of South Africa, the north-western assemblage is not so tightly constrained and it seems likely that the current distribution, and observed patterns of genetic variation within these populations, probably resulted from a combination of vicariance and dispersal events.

The large number of unique mtDNA lineages found in the south-eastern clade, most of which are characterized by relatively high sequence divergences (Table 2), suggest that the constituent populations have been isolated from each other for long periods thus allowing for the accumulation of unique site changs. This is underscored by the $N_{\text {st }}$ values which provide evidence of significant population structure in this clade. Taken together, these results are consistent with the view that the majority of populations sampled within the south-eastern assemblage are old, and that historic gene flow between populations has been limited.

In contrast, the genetic structure of populations comprising the north-western $P$. rupestris assemblage is more enigmatic. Two discrete subclusters are evident from the Neighbour-Joining tree topology (Fig. 3a) as well as from the parsimony network where a minimum of 11 steps separate the Kuruman collection locality (locality A; haplotypes 8 and 9) from the other north-western lineages (Fig. 3b). Particularly noteworthy is the low number of site changes linking the remaining populations, many of which are geographically distant, which is clearly at variance with the general pattern evidenced by populations comprising the south-eastern clade. These data (single site changes and low sequence divergences connecting populations over such a broad distribution area) are consistent with recent dispersal events within the north-western mtDNA clade.

With the possible exception of elevation, no readily apparent ecological or topographical barrier appears to separate the populations comprising the two mtDNA assemblages detected in this study. In fact, the physiognomy of the habitat bridging the two mitochondrial clades appears indistinguishable from that characterizing most of the northern clade. In broad terms, the sample populations of the southeastern assemblage appear to constitute 'high alpine' communities (mean elevation $1933 \mathrm{~m} \pm 292 \mathrm{~m}$; range 1641-2225 m) whereas those of the north-western clade are, with the exception of Kuruman (locality A; see below), generally found at lower elevations $(1469 \mathrm{~m} \pm 86 \mathrm{~m}$; range $1358 \pm 1709 \mathrm{~m})$. In this respect it is revealing that the Kuruman mountains (1855 $\mathrm{m})$, with an elevation more in keeping with the south-eastern clade's populations, show the nearest neighbour connection to the 'high alpine' southeastern assemblage in the parsimony network (45 steps; Fig. 3). We hypothesize that this region represents a relict population of what was historically a more widely distributed south-eastern assemblage and that changing environmental factors, possibly in association with glacial and interglacial periods in the Pleistocene (Deacon \& Thackeray, 1983), may have caused widespread extinction of populations in marginal habitat. (Marginal habitat is typified by 'terrestrial islands' surrounded by the extensive plains of the interior, as opposed to core habitat where discrete populations are distributed within, or in close proximity to, the continuous mountain ranges of the Great Escarpment.) Under this scenario the higher Kuruman elevations $( \pm 1855$ m, 
cf. the $1050 \mathrm{~m}$ of the surrounding plains) and possibly more mesic conditions of the Kalaharithornveld $( \pm 457 \mathrm{~mm}$ annual rainfall, cf the \pm 290 $\mathrm{mm}$ annual rainfall of the Karoo and Karoid plains) provided refugia from which the subsequent recolonization within the marginal habitat of the plains subsequently took place.

Given the essentially parapatric distribution pattern of the two clades (at least in parts of their ranges; Fig. 3b), the absence of shared haplotypes between them and relatively short geographical distances separating some of the clade-specific populations (for example locality $\mathrm{B}$ from $\mathrm{N}$ and $\mathrm{L}$ from Q), one cannot help but question whether species status for the two assemblages could perhaps be justified. Our estimate of a mean sequence divergence of 7.94 per cent between the two clades is higher than what has been previously reported in many other intraspecific studies including those on rodents (Avise et al., 1979b, 1983), horses (George \& Ryder, 1986), fruitbats (Pumo et al., 1988), deer (Carr et al., 1986; Cronin, 1992), peccaries (Theimer \& Keim, 1994) and in the companion study on the rock hyrax (Prinsloo \& Robinson, 1992) and falls more closely within the range previously reported for various interspecific divergences (for example Cronin, 1991; Gill \& Slikas, 1992). But, even more revealing, this value approximates the 8.75 per cent $( \pm 1.43$ per cent) interspecific sequence divergence separating $P$. rupestris from its congener $P$. randensis (Matthee, 1993). Clearly, a definitive statement on this issue is currently not possible as our data merely reflect the results of a single, albeit particularly informative locus. If, however, other discrete character states can be identified that are uniquely shared by the rabbits constituting the mtDNA clades detected in this study, a strong case for species status can certainly be made.

\section{Acknowledgements}

We thank the regional conservation agencies and many private landowners in South Africa for allowing us to conduct research on reserves/farms under their jurisdiction. Drs N. Georgiadis and N. Lehman provided valuable comment on an earlier draft of the manuscript. Financial support from the Foundation for Research Development and the Department of Environment Affairs is gratefully acknowledged.

\section{References}

AVISE, J. C. 1989. Gene trees and organismal histories: a phylogenetic approach to population biology. Evolution,
43, 1192-1208.

AVISE, J. C. 1992. Molecular population structure and the biogeographic history of a regional fauna: a case history with lessons for conservation biology. Oikos, 63, 62-76.

AVISE, J. C., LANSMAN, R. A. AND Shade, R. O. 1979a. The use of restriction endonucleases to measure mitochondrial DNA sequence relatedness in natural populations. I. Population structure and evolution in the genus Peromyscus. Genetics, 92, 279-295.

AVise, J. C., GiBlin-DAVidSON, C., LAERM, J., PATtON, J. C. AND LANSMAN, R. A. 1979b. Mitochondrial DNA clones and matriarchal phylogeny within and among geographic populations of the pocket gopher, Geomys pinetis. Proc. Natl. Acad. Sci. U.S.A., 76, 6694-6698.

AVISE, J. C., SHAPIRA, J. F., DANIEL, S. W., AQUADRO, C. F. AND LANSMAN, R. A. 1983. Mitochondrial DNA differentiation during the speciation process in Peromyscus. Mol. Biol. Evol., 1, 38-56.

AVISE, J. C., ARNOLD, J., BALL, R. M., BERMINGHAM, E., LAMB, T., NEIGEL, J. E., REEB, C. A. AND SAUNDERS, N. C. 1987. Intraspecific phylogeography: the mitochondrial DNA bridge between population genetics and systematics. Ann. Rev. Ecol. Syst., 18, 489-522.

AVISE, J. C., BOWEN, B. W. AND LAMB, T. 1989. DNA fingerprints from hypervariable mitochondrial genotypes. Mol. Biol. Evol., 6, 258-269.

BIJU-DUVAL, C., ENNAFAA, H., DENNEBOUY, N., MONNEROT, M., MignotTE, F., SORIGUER, R. C., EL GAAIED, A., EL HiLl, A. AND MOUNOLOU, J. 1991. Mitochondrial DNA evolution in Lagomorphs: origin of systematic heteroplasmy and organization of diversity in European rabbits. J. Mol. Evol., 33, 92-102.

BRISTOW, D. AND WARD, C. 1988. Mountains of Southern Africa, pp. 1-125. C. Struik Publishers, Cape Town.

BROWN, w. M. 1983. Evolution of animal mitochondrial DNA. In: Nei, M. and Koehn, K. K. (eds) Evolution of Genes and Proteins, pp. 62-88. Sinauer Associates, Sunderland, MA.

CARR, S. M., BALLINGER, S. W., DERR, J. N., BLANKENSHIP, L. H. AND BICKHAM, J. w. 1986. Mitochondrial DNA analysis of hybridization between sympatric white-tailed deer and mule deer in west Texas. Proc. Natl. Acad. Sci. U.S.A., 83, 9576-9580.

CRONIN, M. A. 1991. Mitochondrial DNA phylogeny of deer (Cervidae). J. Mammal., 72, 533-566.

CRONIN, M. A. 1992. Intraspecific variation in mitochondrial DNA of north American cervids. J. Mammal., 73, $70-82$.

DEACON, H. J. AND THACKerAy, J. F. 1983. Late Pleistocene environmental changes and implications for archaeological record in southern Africa. In: Vogel, J. C. (ed.) Proceedings of SASQUA International Symposium, pp. 375-390. AA Balkema, Rotterdam.

ELLERMAN, J. R., MORRISON-SCOTT, T. C. S. AND HAYMAN, R. w. 1953. Order Lagomorpha. In: Southern African Mammals 1758 to 1951; a Reclassification, pp. 212-222. British Museum (NH), London.

FEINBERG, A. P. AND VOGELSTElN, B. 1983. A technique for radiolabeling DNA restriction endonuclease fragments 
to high specific activity. Analyt. Biochem., 132, 6-13.

GEORGE, M. AND RYDER, O. A. 1986. Mitochondrial DNA evolution in the genus Equus. Mol. Biol. Evol., 3, 535-546.

GILL, F. B. AND SLIKAS, B. 1992. Patterns of mitochondrial DNA divergence in North American crested titmice. Condor, 94, 20-28.

JUKES, T. H. AND CANTOR, C. R. 1969. Evolution of protein molecules. In: Munro, H. N. (ed.) Mammalian Protein Metabolism, pp. 21-132. Academic Press, New York.

LANSMAN, R. A., SHADE, R. O., SHAPIRA, J. F. AND AVISE, J. C. 1981. The use of restriction endonucleases to measure mitochondrial DNA sequence relatedness in natural populations. III. Techniques and potential applications. J. Mol. Evol., 17, 214-226.

LYNCH, M. AND CREASE, T. J. 1990. The analysis of population survey data on DNA sequence variation. Mol. Biol. Evol., 7, 377-394.

MATTHEe, C. A. 1993. Mitochondrial DNA Variability and Geographic Population Structure in Pronolagus rupestris and P. randensis (Mammalia: Lagomorpha). M. Sc. Thesis, University of Pretoria.

MEESTER, J. A. J., RAUTENBACH, 1. L., DIPPENAAR, N. J. AND BAKER, C. M. 1986. Classification of southern African mammals. Transvaal Mus. Monogr., 5, 1-359.

NEI, M. AND MILlER, J. C. 1990. A simple method for estimating average number of nucleotide substitutions within and between populations from restriction fragment data. Genetics, 125, 873-879.

NEI, M. AND TAJIMA, F. 1981. DNA polymorphism detectable by restriction endonucleases. Genetics, 97,
$145-163$.

PETTER, F. 1972. Order Lagomorpha, Part 5. In: Meester, J. and Setzer, H. W. (eds) The Mammals of Africa: an Identification Manual, pp. 1-7. Smithsonian Institute Press, Washington DC.

PRINSLOO, P. AND ROBINSON, T. J. 1992. Geographic mitochondrial DNA variation in the rock hyrax, Procavia capensis. Mol. Biol. Evol., 9, 447-456.

PUMO, D. E., GOLDIN, E. Z., ELLIOT, B., PHILLIPS, C. J. AND GENOWAYs, H. H. 1988. Mitochondrial DNA polymorphism in three Antillean island populations of the fruit bat, Artibeus jamaicensis. Mol. Biol. Evol., 5, 79-89.

RoberTs, A. 1951. The Mammals of South Africa. Trustees of the Mammals of South Africa Book Fund, Johannesburg.

RYDER, O. A. 1986. Species conservation and systematics: the dilemma of subspecies. Trends Ecol. Evol, 1, 9-10.

SAITOU, N. AND NE1, M. 1987. The Neighbor-Joining method: a new method for reconstructing phylogenetic trees. Mol. Biol. Evol., 4, 406-425.

SLATKIN, M. 1987. Gene flow and the geographic structure of natural populations. Science, 236, 787-792.

SMITHERS, R. H. N. 1983. Order Lagomorpha. In: Smithers, R. H. N. (ed.) The Mammals of the Southern African Subregion, pp. 160-169. University of Pretoria, Pretoria.

SOUTHERN, E. M. 1975. Detection of specific sequences among DNA fragments separated by gel electrophoresis. J. Mol. Biol., 98, 503-517.

THEIMER, T. C. AND KEIM, P. 1994. Geographic patterns of mitochondrial DNA variation in collared peccaries. $J$. Mammal., 75, 121-128. 